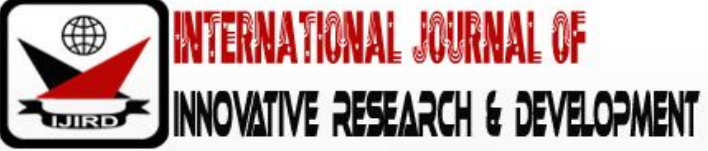

ISSN 2278 - 0211 (Online)

\section{Assessment of Goat Production and Marketing System in Ofa Woreda Wolaita Zone, Southern Nations Nationalities People of Region (SNNPR), Ethiopia}

\author{
Workineh Menna \\ Lecturer, Department of Statistics, Wolaita Sodo University, Ethiopia
}

\begin{abstract}
:
The study was conducted in Ofa Woreda, Wolaita Zone, SNNPR with the objective of assessing goat production and marketing system with 173 samples household were randomly selected. Both primary and secondary sources of data were used by using self-administered questionnaires and it was analyzed using descriptive statistics. Such as frequencies, means and percentage then results were presented in tables. In this study $78.7 \%$ of respondents were male house hold headed, $22.3 \%$ of the respondents were female house hold headed. In this area the farmers have got goat from governmental organization of Agricultural office of the district, and private by buying and selling from local market. The main purpose of keeping goat in the study area for income generating, saving, milk and manure. All of the respondents raise goat in mixed farming system with crops. The dominant feeding sources were natural grazing, non-conventional feed and industrial by products. Marketing issues considered color, height, body size stage of pregnancy and age were used for buying and selling goat production were the major means of livelihood for the farmers in the area. However, the production problems in the study area were disease poor quality of goat varieties. Lack of credit services, shortage of food for goats, extension services, grazing land, and poor of market information and markets availability. But in the area, there are opportunities that were increased market access, Credit services, seasonal availability of feed and water access better weather condition, demand of products and extension service. Therefore, in order to improve Goat production and minimize constraints by training of farmers engaged in the sectors if important. It is recommended improve farmers management practice through training crate awareness.
\end{abstract}

Keywords: Goat, Ofa Woreda, production, marketing system

\section{Introduction}

\subsection{Background of the Study}

Agriculture has many important roles in the Ethiopian economy. Ethiopia has divers agro-ecological zones suitable for livestock production. By becoming more responsible for environment and strengthening relationships with rural areas. Agriculture has assumed social roles besides its economic ones the livestock sector faces domestic resources constraints (limited feed supply) and heavily pressure from cheaper livestock important the performance of the livestock sector in sub-Saharan Africa over most of the last two decades has been far from impressive. The production and consumption gap for the major food a commodity has widened across the continent. More than 90 percent of these goats are located in Asia and Africa, with only 1.8 percent in Europe. Where decrease and a pain are the countries with the most leads. Over the past 50 years, the goats' populations have multiplied by 2.4 times, while other livestock species have maintained or decreased their population. About 1 billion goats (1996 120 851) FAOSTAT, 2013).

Goat have been the most rapidly expanding livestock subsector for more than 20 years. The world goat's population has increased by about 66 percent over the past 20 years. Compared with 14 percent growth for cod the (FAOSTAT, 2013). However most of this growth has accrued in low income countries (which account for about 80 percent of the world's goats) and most of the goat milk or meat produced for own consumption farms, with ovary small share traded probably loss than percent (Dubeut et al, 2004).

Goat population is immense in Ethiopians estimated at 22.6 million heads (ESA, 2016). It is found widely distributed across the different agro-ecological zones of the country (EARO, 2000). Google are found by small holder farmers as an integral part of livestock sub-setter (Tekely and Kasali, 1992) and contribute to both substance and east income generation (EARO, 2000).

Goat production plays a vital role in the live hood of small-scale farmers from livestock and an important component of agricultural activities in southern Africa and developing countries. It is the most important agricultural activity in most of the countries in south. Goat production kept for various uses including drought power, milk, meat and 
various cultural uses. They complement cropping fixities through the provision of manure for soil fertile maintenance of drought power for cultivation transport cash and food (poweledas, 2004).

Goat production system are generally characterized by low productivity production in communal areas in subSaharan Africa is constrained by a verity of factor. Feed shortages during the dry season constitute the greatest challenges in terms of quality and quantity (Mas kati, 2010).

The main constraint to increase livestock productivity and output is the lack of adequate supplies of good quality livestock feed in the drag season produced at competitive east and without jeopardizing house hold food security. Together with high incidences of the disease and mortality rates feed shortage lead to livestock productivity (Masikati, 2010) unavailability of water is another common constraint. In some areas, water may be available but insufficient quality to support heals thing growth and performance (Maskati, 2010). Supported, that water constraints were prevalent during the dry season, where animals had to walk distance of up to $14 \mathrm{~km}$ per day \& access water.

\subsection{Statement of the Problem}

Goats kept in the vast geographical location's diverse socio economic and cultural settings and range of farming practices in the SNNPR play immense role in the livelihood of rural farms agrees and in Ofa Woreda in particular. The lack of up to data and specific information on production and marketing systems often a major limitation to productivity improvement endeavors in goats (peters and Horpens 1989).

As population pressure increases further and farm sizes decrease the role of large ruminants reduces and small ruminants that constitute less competition for arable land predominant (Jahnke, 1982).

However, the information about goat production systems marketing, opportunities and constants is not easily available which is very important of production around the study area.

\subsection{Objectives of the Study}

- General objectives

To investigate factors preventing goat production and marketing system.

- Specific objectives

To identify goat production system in the study area

To assess goat marketing system in the study areas

\section{Literature Review}

\subsection{Goat Production System}

Goat production contributes significantly to human livelihoods through the provision of food directly through meat and milk and indirectly by increasing farmers ability to buy food study of had produced on farm. The goat was one of the first animals to be domesticated by humans about 9,000 years ago. Foray there are some 200 different breeds of goats that produce a variety of products including, milk, meat and fiber (Moha and Cashmere). Worldwide goat meat production is higher than meat production from cattle or hogs. (Hollcom, 1994).

Goats can be kept in extensive, semi intensive and intensive production systems depending on the availability of land.

\subsubsection{Extensive Production System}

Under this system goats are allowed to browse (free range) freely. This system is suited for areas where browsing fields are not a problem to be effective for daily goats. The flock holds have stockman (herelman) and the males should be separated from the does to random mating kinds should also be separated from the does to avoid sucking while in the field. The goats should be supplemented with concentrate feeds and mineral salts. The goats should be provided with housing (night slide) with $1 \mathrm{~m}^{2}$ for each goat. Good goat housing should be dry, well ventilated and provides kids, does and bucks a healthy comfortable condition. The housing should also provide security from predators.

\subsubsection{Intensive Production System}

This system is suited for areas where browsing fields are limited. It is suited for small size of flack and where land is limited. It involves confinement of the goats the goat is stall feed (zero-grazing exclusively and mating is controlled does, backs and kinds are housed separately workneh,1999, EARO 2001.

Good goat housing should be dry, well ventilated and provide kinds, does and backs healthy comfortable condition. The housing should also provide security from predators and thieves (Tembely, 1998,EARO 200).

\subsubsection{Semi-Intensive Production Systems}

This system combines the intensive and extensive systems goats are allowed to browse but also star feed to complement browsing. In addition, the goats should be supplemented with concentrated and mineral salts. Water should be available all the time. Mating is controlled by separating the back and does separately. In most case the bucks are completely stall-feed and females on heat are brought to the back for mating. This is-important helps to control the all flavor in milk and inbreeding (Adane and Girma, 2007). 


\subsection{Goat Management}

Goat productions contribute significantly \& human level hoods the provision of food, directly through meat and milk and indirectly by increasing farmer's ability to buy food staff not produced on farm. The goat was one of the first animals to be domesticated by humans about 9.000 years ago. In Ethiopia there are so many numbers of small ruminant animals due to favorable agro-ecological condition.

However, goats represent an important component of the farming system by providing about $12 \%$ of the value of livestock products consumed and 98\% of the cash income generation at the farm level (kassahunet al 1989).

\subsubsection{Feeding Management}

Farmers depend on natural range lands to feed their goats. However, these feed resources become limited in quantity and also vary from the prevailing weather conductions. During the dry season the range lands less, feed quality and are not sufficient to maintain goat's health conditions. According to farmers information feed shortage are common during the months of December to march dry season feeding is of high priority to them in order to alleviate feed shortage and ensure the survival of goats (VanRoayey and hamann, 2008).

The main cause of high morality rotes is poor management practices and more specifically lacks of dry season feed poor animals health and housing addressing these factors individually or collectively can substantially reduce, mortalities (van Rooyen and Homann, 2008).

\subsubsection{Health Management / Condition}

Effective management of animal's health can reduce the morality rotes of goats. Which are highest during the dry season specific and hence requires delight and timely attention (Vam Roogen and Homann, 2008). During the dry season the most common disease maintained was pulpy kidney (enterotoxaemia), followed by helminthosis (internal parasite tick-borne diseases, mange (external parasites) and eye problems.

To a lesser extent, goats suffered from pastoral dermatitis (orf) and food rot. Other diseases included good and mouth disease, anthrax, sadden mortality and gid (Taeniamultieeps) coenuruscerebralis) Homann et al, 2007).

\subsubsection{Housing Management}

Most farmers house their goats in open kraals. They lack the awareness that appropriate shelter can prevent many goat's disease and reduce mortality rates. Especially for goat kids. Kids are highly vulnerable to cold and wet period and soon succumb to exposure. Many farmers also seem to be unaware that very effective goat shelters can be built from local materials costing little more than the price of labor.

Proper housing would protect animals against wind, cold, disease risks rain and muddy condition which private during the rainy season (Vanrooyen and Vomann, 2008).

In the rainy season more, farmers housed their goats under root than compared to the dry season. The period of investment housing coin vided with increased disease risk (foot rot, pneumonia) in directing farmer's awareness of the effect of the rainy season on animal health (Homann et al2007).

\subsection{Support Management (Services)}

The absence of adequate support services strategies prevents farmers from adapting the right Techniques to improve production and delays farmers and market response to the demand. Support services need to play a stronger role in disseminating adequate information and facilitating multi stockholder processes in technology and market development (VanRoyen and Homann, 2008), high yielding breeds often have weak udders that are unsuitable for harsh environment (Gutierrez et al2000).

\subsection{Goat Marketing}

Marketing includes moving product from producers to consumers and comprises exchange activities of buying and selling the physical activity designed to give the product increased time place and farm ability and the associated functions of financing risk bearing and dissemination of information to participants in the marketing process (Tabberetal 1997).

Goat marketing involves the sale, purchase or exchange of product such as live animals and livestock products of milk meat skins wool and hides cash or goods in kind. (ILCA.1990).

Farmers a ware of the preferred characteristics of animals well as price pattern. So that they can plan breading and fattening programs and bread selection consistent with the best seasonal prices and consumers preferences (Peter and Horpew, 1989 et al 2000). Marketing of goat's characterized by starting seasonality and subject to qualifications a demand and price increases during festival periods.

Factors affecting market supply as measured by the number offered as well as cash needs for crop inputs and later for food purchase before harvesting (EARO 2000).

Associated with the production to consumption market is the need for a proactive agribusiness orientation (Deuendra,2007)

Low goat productivity affects the market sub-sector as small numbers of marketable goats and poor goat quality would attract only few buyers. This results in low market volumes and persisting demand supply gap for goat meat the lack of adequate production and marketing strategies prevents the supply of sufficient goats (number and quality) to the consumer (Van Rooyen and Homann, 2008). 


\section{Materials and Methods}

\subsection{Description of the Study Area}

The study was conducted in Ofa Woreda which is found in Wolaita Zone, south nations nationality and people of Ethiopia. The Woreda is located $383 \mathrm{~km}$ away from Addis Ababa, the capital city of Ethiopia and 183km from regional city, Hwassa,29 km away from Wolaita Sod, is the Zonal city of the area. The Woreda is located in latitude of north 60 44'59.99' and 37029'59.99' degree longitude of east having altitudes ranging of 1200-2000 masl. The total area is 38537 hectares. The amount of rain fall and range of temperature were $800-1400 \mathrm{~mm}$ and $14-340 \mathrm{C}$ respectively.

Based on the 2007 Census conducted by the CSA, this woreda has a total population of 103,870, of whom 50,938 are men and 52,932 women; 5,426 or 5.22\% of its population are urban dwellers. The majority of the inhabitants were Protestants, with $85.55 \%$ of the population reporting that belief, $11.97 \%$ practiced Ethiopian Orthodox Christianity, and $1.1 \%$ was Catholic. Agricultural system of the Offa woreda is defined by mixed farming system, livestock production, and crop production. The dominant corps in the area coverage, production and consumers number in the study area is: maize, haricot bean, teff, and root crops like cassava and sweet potatoes and the majority of low land area residential are mainly producing goat.

\begin{tabular}{|c|c|c|}
\hline No & Species & Ahead of livestock \\
\hline 1 & Cattle & 146,230 \\
\hline 2 & Goats & 81140 \\
\hline 3 & Sheep & 26001 \\
\hline & Total ruminants & 253,372 \\
\hline 4 & Horses & - \\
\hline 5 & Mules & 34 \\
\hline 6 & Donkey & 16,920 \\
\hline & Total & 16954 \\
\hline 7 & Chickens & 162366 \\
\hline
\end{tabular}

Table1: Ofa Woreda Livestock Population in 2016

Source: Ofa Woreda Agricultural Office (HWAO, 2016)

\subsection{Sampling Techniques and Sampling Size}

The Woreda has three agro-ecological zones. That is low land, mid land and highland and Wored as have 26 rural kebeles of which 13 are found in low land, 9 mid land and 4 are high land respectively. To collect primarily data, we select purposively the low land and mid land Kebeles since they mainly produce goat among livestock. Second stage sampling were used at $1^{\text {st }}$ stage 3 and 2 kebele were separated randomly from low land and mid land respectively. At the second stage 175 households whose were selected by employing Stratified random sampling method.

\subsection{Data Collection Methods}

Both primary and secondary sources were used, the primary data was collected from sampled respondents through semi structured questioner and interview with key informant were used to collected survey data.

The questionnaire was designed to capture information such as household demographic including gender,age and education background of the respondent. Production practices including species kept identification of production and marketing system. Management practices to include feeding watering breading and health provision. Secondary data was collected from different literature materials and from Ofa Woreda Agricultural office.

\subsection{Data Analysis}

The collected data were summarized and analyzed by using descriptive statistics such as frequencies, means and percentage. Then the results were presented in the tables and graph forms.

\section{Result and Discussion}

The main aim of this study was to investigate factors that preventing goat production and marketing system of Ofa Woreda, Wolaita Zone. The data were cross sectional and it was collected on the goat production and marketing system from period January 2016 to February 2016. The sample size determined for this study was 175, but 2 of them could not respond to the questionnaire well. So, the analysis was based on information and data obtained from 173 respondents.

\subsection{The Respondent Profiles}

The following table show that the respondent profile of frequency and percentage with the respective category. 


\begin{tabular}{|c|c|c|c|}
\hline Factor & Category & Frequency & Percentage \\
\hline Gender of the Respondent & Male Headed & 136 & 78.6 \\
\hline & Female headed & 37 & 21.4 \\
\hline Age & $<40$ & 39 & 22.5 \\
\hline & $41-45$ & 76 & 43.9 \\
\hline & $46-50$ & 18 & 10.4 \\
\hline & $>50$ & 40 & 23.2 \\
\hline & Can't read and write & 18 & 10.5 \\
\hline Education & Primary (1-4) & 39 & 22.5 \\
\hline & Junior (5-8) & 58 & 33.5 \\
\hline & Grade (9-10) & 58 & 33.5 \\
\hline & Married & 173 & 100 \\
\hline
\end{tabular}

Table 2: Demographical Characteristics of the Respondent

As indicated in Table 2 above $78.6 \%$ and $21.4 \%$ of the respondent were male and female respectively, where as $43.9 \%$ of the respondent were under the age of $41-45$ years category and $10.4 \%$ of the respondent were in the category of 46-50 years level, and 33.5\% of the respondent were at the grade level of 5-8 and 9-10 whereas $10.5 \%$ of the respondent were can't read and write and 22.5\% were primary(1-4) grade level of education. All respondent was married.

\subsection{Population of Livestock in the Study Area}

In the following Table 3 try to show the average value with their respective variance and standard deviation of population of livestock in the study area.

\begin{tabular}{|c|c|c|c|c|c|c|}
\hline Characteristics & N & Min. & Max. & Mean & Std. Deviation & Variance \\
\hline Numbers of cow & 173 & 1 & 2 & 1.44 & 0.527 & 0.278 \\
\hline Numbers of Bulls & 173 & 0 & 1 & 0.33 & 0.500 & 0.250 \\
\hline Numbers of Heifers & 173 & 0 & 1 & 0.56 & 0.527 & 0.278 \\
\hline Numbers of Male Calves & 173 & 0 & 1 & 0.78 & 0.441 & 0.194 \\
\hline Numbers of Females Calves & 173 & 0 & 1 & 0.22 & 0.441 & 0.194 \\
\hline Numbers of Ox & 173 & 1 & 2 & 1.44 & 0.527 & 0.278 \\
\hline Numbers of Goat flack & 173 & 4 & 8 & 5.33 & 1.414 & 2.000 \\
\hline Numbers of Goat Kids (<3 months) & 173 & 0 & 2 & 1.44 & 0.726 & 0.528 \\
\hline Numbers of Goat Back kids (3-6 months) & 173 & 0 & 1 & 0.56 & 0.527 & 0.278 \\
\hline Numbers of Goat kids (6-12 month) & 173 & 0 & 0 & 0.00 & 0.000 & 0.000 \\
\hline
\end{tabular}

Table 3: Livestock Distribution in the Study Area

Table 3 Shows that the mean number of cows, Ox and the mean numbers of goat kids of the respondent were 1.44, and the mean number of goats were 5.33 and the minimum and maximum number of got were 4 and 8 respectively.

\subsection{Purpose of Goat Production ( or Keeping Goat)}

In the study are goat were produced for different purpose as collected through open ended questioner and from my experience goat were mainly produced to saving, for use of manure, selling for different purpose, for meat, for milk and for social and cultural functions.

\begin{tabular}{|c|c|c|c|}
\hline Factor & Category & Frequency & Percentage \\
\hline \multirow{3}{*}{$\begin{array}{c}\text { Purpose of goat } \\
\text { production }\end{array}$} & Sales & 28 & 16.1 \\
\cline { 2 - 4 } & meat & 15 & 8.5 \\
\cline { 2 - 4 } & milk & 7 & 4.0 \\
\cline { 2 - 4 } & manure & 44 & 25.4 \\
\cline { 2 - 4 } & sacrifices & 7 & 4.0 \\
\cline { 2 - 4 } & social and cultural functions & 16 & 9.2 \\
\cline { 2 - 4 } & Saving & 51 & 29.5 \\
\cline { 2 - 4 } & Distributes benefits & 6 & 3.3 \\
\hline
\end{tabular}

Table 4: Purpose of Goat Production 
The current study in Table 4 revealed that the main reason of keeping goat were for saving, for use of manure, for sales in the following percentage $29.5 \%, 25.4 \% 16.1 \%$ respectively. These is consistent with different study like (Hollcom, 1994), and (kassahunetal-1989).

\subsection{Sources of Veterinary Service and Types of Diseases}

In the study area as the district report showed that there were limited veterinary service and there were some types of diseases, some of the diseases were found from the study area with open ended questioners, foot rot, pneumonia and Mite these is almost similar with the study result of (Taeniamultieeps, coenuruscerebralis, Homann et al, 2007).

\begin{tabular}{|c|c|c|c|}
\hline Factor & Category & Frequency & Percentage \\
\hline \multirow{3}{*}{ When Goat Sick } & takes to veterinary center & 115 & 66.5 \\
\hline & $\begin{array}{c}\text { treat with treatments from local } \\
\text { trader }\end{array}$ & 58 & 33.5 \\
\hline & Total & 173 & 100.0 \\
\hline \multirow[t]{4}{*}{ Source of Veterinary Service } & Government office & 125 & 72.2 \\
\hline & Private institution & 28 & 16.2 \\
\hline & Open market & 20 & 11.6 \\
\hline & Total & 173 & 100.0 \\
\hline \multirow{3}{*}{ veterinary services are in near distance } & Yes & 155 & 89.6 \\
\hline & No & 18 & 10.4 \\
\hline & Total & 173 & 100 \\
\hline \multirow{3}{*}{$\begin{array}{c}\text { How did you obtain services from these } \\
\text { institution }\end{array}$} & free of charge & 18 & 10.4 \\
\hline & payment & 155 & 89.6 \\
\hline & Total & 173 & 100 \\
\hline \multirow{3}{*}{$\begin{array}{l}\text { Have you vaccinated your goats in recent } \\
\text { times }\end{array}$} & Yes & 115 & 66.5 \\
\hline & No & 58 & 33.5 \\
\hline & Total & 173 & 100 \\
\hline \multirow[t]{3}{*}{ If "Yes" when } & after report of disease causes & 39 & 22.5 \\
\hline & before out breaks & 134 & 77.5 \\
\hline & Total & 173 & 100 \\
\hline \multirow[t]{2}{*}{ medicines and drags from open market } & Yes & 18 & 11.1 \\
\hline & No & 154 & 88.9 \\
\hline \multirow[t]{3}{*}{ Source of medicines } & Gov't veterinary clinic & 113 & 65.3 \\
\hline & Open market & 60 & 34.7 \\
\hline & Total & 173 & 100 \\
\hline
\end{tabular}

Table 5: Factors Related with Veterinary Service

As indicated in Table 5 majority $66.5 \%$ of the respondent were took their goats to veterinary clinic where as $33.5 \%$ of the respondent were treat with what locally available in traditional way. Most of the respondent (72.2\%) were answered that the source of medication (or drug) was government office but few of them (16.2\%) were used private institution and $11.6 \%$ were used from open market.

\begin{tabular}{|c|c|c|c|}
\hline Parameter & Level & Frequency & Percentage (\%) \\
\hline Source of water & River & 173 & 100.0 \\
\hline \multirow{3}{*}{ Frequency of watering } & Once a day & 134 & 77.5 \\
\hline & Twice a day & 39 & 22.5 \\
\hline & Total & 173 & 100 \\
\hline How goats browse & together with other livestock & 173 & 100.0 \\
\hline \multirow{3}{*}{ browsing your goats in the dry season } & free grazing & 39 & 22.5 \\
\hline & Party kept tethered grazing & 134 & 77.5 \\
\hline & Total & 173 & 100 \\
\hline \multirow{3}{*}{$\begin{array}{l}\text { Do you usually provide your goats } \\
\text { with supplementary feeds }\end{array}$} & Yes & 133 & 76.8 \\
\hline & No & 40 & 23.2 \\
\hline & Total & 173 & 100 \\
\hline \multirow{3}{*}{$\begin{array}{l}\text { When do you usually offer your goats } \\
\text { with supplements }\end{array}$} & Dry season & 155 & 89.6 \\
\hline & both & 18 & 10.4 \\
\hline & Total & 173 & 100 \\
\hline \multirow{3}{*}{ Is there feeds shortage } & No & 44 & 25.4 \\
\hline & Yes & 129 & 74.6 \\
\hline & Total & 173 & 100 \\
\hline \multirow[t]{3}{*}{ If "Yes" when } & Dry season & 97 & 56.1 \\
\hline & both & 76 & 43.9 \\
\hline & Total & 173 & 100 \\
\hline
\end{tabular}

Table 6: Source of Water and Frequency of Watering 
As Table 6 indicated that all of the respondent (100\%) were used river as source of water and $77.5 \%$ and $22.5 \%$ were respond as watering their goat once a day and twice a day respectively.

All of the respondent that is $100 \%$ of respondent were browse their goats together with other livestock, $76.8 \%$ of the respondent were provide supplementary feeds to their goats where as $23.2 \%$ not and $74.6 \%$ of the respondent were said that we face the shortage of feed, this is mostly in the dry season. From open ended question most of the respondents were said that the source of supplementary feed was cereals and food waste. The current study result is similar with (VanRoayey and hamann, 2008) study result.

\begin{tabular}{|c|c|c|c|}
\hline Parameter & Level & Frequency & Percentage (\%) \\
\hline \multirow{3}{*}{$\begin{array}{c}\text { Have you sold your goats in the past } 12 \\
\text { months }\end{array}$} & No & 39 & 22.5 \\
\hline & Yes & 134 & 77.5 \\
\hline & Total & 173 & 100.0 \\
\hline \multirow[t]{4}{*}{ If "Yes" why } & for household consumption & 57 & 33.0 \\
\hline & for agricultural input buying & 77 & 44.5 \\
\hline & Not sold & 39 & 22.5 \\
\hline & Total & 173 & 100.0 \\
\hline \multirow[t]{3}{*}{ Where do you sold your animals } & Local market & 76 & 43.9 \\
\hline & At Woreda's district Market & 97 & 56.1 \\
\hline & Total & 173 & 100.0 \\
\hline \multirow[t]{4}{*}{ Who participate in buying goat } & Father only & 140 & 80.9 \\
\hline & Mother only & 12 & 6.9 \\
\hline & Both (Father and Mother) & 21 & 12.2 \\
\hline & Total & 173 & 100 \\
\hline
\end{tabular}

Table 7: Goat Marketing System

As Table 7 shows that $77.5 \%$ were sold their goat in the past 12 months but $22.5 \%$ of the respondent not sold. Among the respondent $33.0 \%$ and $44.5 \%$ were sold their goat for household consumption and for agricultural input buying respectively but as mentioned above $22.7 \%$ were not sold for the last 12 months and $43.9 \%$ and $56.1 \%$ of the respondent were sold their goat in local market and at Woreda's district Market. As these studies revealed that $80.9 \%$ of the respondent were said that only fathers participate in buying goat where as $12.2 \%$ and $6.9 \%$ of the respondent were Both (Father and Mother) and mother only in goat buying and selling time.

Form open ended questions there are a lot of information were collected, some of them was about factors based on marketing issues of goat considered color, height, body size, stage of pregnancy and age were used for buying and selling goat production is the major means of livelihood for the farmers in the study area. And the problem of production of goat were diseases, shortage of grazing place, shortage of water specially in dry season, shortage of access of varieties of goat and shortage of availability of veterinary service were identified as the major and common problem of the study area of goat production.

\section{Conclusion and Recommendation}

\subsection{Conclusions}

The main objective of the study was to identify the factors that affect the goat production and marketing system in Ofa Woreda, wolaita Zone. In order to determine values of the response variable, goat production and marketing system, different factors were assessed. The conclusions made based on the analysis are as follows:

Based on the analysis, of $78.6 \%$ of respondents were male headed, $22.4 \%$ of the respondents were female headed. In this area the farmers have got goat from organization Agricultural office, and private by buying and selling. The main purpose of keeping goat in the study area were for income, distribute the goats to other for more goats, meat, saving, milk and manure.

From the result all of the study of the respondent was browse their goats with other livestock and most of the respondent were sold their goat in woreda level market and some of them were sold in local market because of these they faced many challenges of marketing system.

The major factors that affecting goat production and marketing system were: grazing with other livestock, shortage of water to goat watering, market for goat selling, shortage of veterinary service and shortage of capital for goat production.

\subsection{Recommendations}

Predictor variables such as grazing with other livestock, shortage of water to goat watering, market for goat, shortage of veterinary service and shortage of capital for goat production, and some other factors were the most probably affecting goat production and marketing system. Having these in mind we make the following recommendations:

To increase the productivity is to improve the life style of the householder. Since $95 \%$ of the population of the study area was rural and the main contribution of income is livestock and farming activities. It is possible to increase the production and marketing system of goat through increased awareness of farmers to use improved varieties of goat since in the study all of the respondent were produce the local (or indigenous varieties), providing additional water resources to goat 
watering, the concerning bodies have to provide as customers need veterinary service since demand and supply was not equal. Paying attention to goat production and marketing system to improve the life style of small household taker, since goat is the major staple livestock in the study area.

Introducing further agricultural research and extension, efficient use of new improved goat, and training farmers, should receive priority attention in policy making.

\section{References}

i. Adane, H. and Girma A. (2001), "Economic significance of goats in Alemu, Y. and Merkel, R.C., Eds., goat production handbook for Ethiopia ESGPIP (Ethiopian sheep and goat productivity improvement program). Addis Ababa, Ethiopia.

ii. Capote, J., Darmanin, N., Delgado, J.V., Fresno, M., López, J.L., (1992(a))Agrupación. Caprina Canaria. Consejería de Agricultura y Pesca. 37 pp, (Anexo pag 29).

iii. Central statistical Agency of the federal democratic republic of Ethiopia, CSA(2012), "Agriculture sample survey of 2011/ 12. (2004 E.C), volume II report on livestock and livestock characteristics (private peasant Holdings) central statistical Agency, Addis Ababa Ethiopia".

iv. Dubeut, J.P., R. Morand-Fehr and R. Rubino, (2004). Situation, changes and future of goat industry around the world. Small Ruminant Research 51 165-173..

v. Ethiopian agriculture research organization (EARO) (2000),"national small ruminant research strategy documents Addis Ababa, Ethiopia.FAO (food and agriculture organization of the united nation 19994, production year book food and agriculture organization.

vi. Gutierrez, C., Rodriguez, M., Sagrera, M,C., padron, T:R and Doreste, F (2000). Carcinoma de cellulasescamesasenmama pigment odes de capirnoencanarias, Rev Medicinal. Veterinarian 17 (1): 26-28.

vii. Holcomb, George- 1994.A small scale agriculture alternative dairy and meat Goats.

viii. Homann, S., van Rooyen, A., Moyo, T. and Nengomasha, Z. (2007). "Goat production and marketing: Baseline information for semi-arid Zimbabwe, Bulawayo, Zimbabwe: International Crops Research Institute for the SemiArid Tropics. $84 \mathrm{pp}$.

ix. JahnkaHaWE (1982). Livestock production systems and livestock development in tropical Africa.

x. Kassahun, A.,Getachew, G., Zelalem, A., Nigussie, A. and Festclor (1989). Goat production in Ethiopia: institute of agricultural roseaid (IAR).proceeding's third national livestock improvement conference 74-26 may 1989. Addis Ababa Ethiopia Pp.78-81.

xi. Mamabolo,MJ. and Webb, EC (2005). Goat production survey fundamental aspects to model goat production system in southern Africa; case study Agricultural commission.

xii. Masikatip (2011). Improving the water productivity of integrated crop-livestock systems in the semi-arid tropics of Zimbabwe: an ex-ante analysis using simulation modeling, Retrieved January 17, 2012.

xiii. Peters, K., and Horpew, T., (1989). Trends in on farm performance testing of cattle goat in sub Saharan Africa. ILCA Bullatin N, 35 December 198. International livestock center for Addis Ababa Ethiopia.

xiv. Powell, JM., Personal, RA. and Hieroglyph (2004). Review and interpretation crop. Livestock interactions in the West African portland. Agro Aa my Journal 96; 469-483

xv. Sibanda, R. (2005). Livestock development in southern Africa future research and investment priorities. Zimbabwe country report, po.Box 776, Buluwayo, Zimbabwe; international crops small ruminant research 51(2004) 165-173.

xvi. Tibebu Tera and Zin abu Wolde (2016).Climate Change Impacts on Agriculture and Adaptive Strategies of the Farming Community in Offa Woreda, Wolaita Zone SNNPR, (2016) pp 50-59 doi 10.20448/ 803.1.2.50.59

xvii. TekelyeBekele and kasali, O.B.(1992). The effect of endoprasize on the productivity of Ethiopian highland goat, keyB, lebbie GH.B and Reyholds L. (1992) small ruminant research and development in Africa proceedings of the first Biennialconference of the African small ruminant research Net. Work ILKAD.ILCA Nairobi keniya; Lo-LA December 1990.

xviii. Van Rooyen and Homann (2008). Enhancing incomes and livelihoods through improved farmers' practices on goat production and marketing: Proceedings of a workshop organized by the Goat Forum, 2-3 October 2007, Bulawayo, Zimbabwe. PO Box 776, Bulawayo, Zimbabwe: International Crops Research Institute for the Semi-Arid Tropics. $84 \mathrm{pp}$. 